\title{
The Factors Influencing Grade VIII Students' Verbal Participation In English Class
}

\author{
Stakisia Puteri Pradestina, Atalya Agustin \\ stakisia.pradestina@sdh.or.id, atalya.agustin@uph.edu \\ Fakultas Ilmu Pendidikan, Universitas Pelita Harapan
}

\begin{abstract}
This study was held to identify the factors behind students' lack of verbal participation in English class. This research was a qualitative case study research, with 26 students of grade VIII at one private school in Jakarta as the subject of research. The instrument used was questionnaire which analyzed using thematic-analysis method. The results showed there are five factors influencing students' lack of verbal participation. It started from teacher's personality that makes the students having lack of self-efficacy in English lesson, lack of self-confidence in speaking English, lack of preparation before the English class begins, and the fear of making mistakes and being laughed at by others. This study also suggested some teaching strategies that could be used by the teachers to improve students'verbal participation in English class or to overcome the factors behind students' lack of verbal participation, such as Inquiry-Based Learning (IBL), Contextual Teaching Learning (CTL), and Cooperative Learning (CL).
\end{abstract}

Keywords: Classroom Participation, English Class, Verbal Participation

Article Info

Received date: 23 Agustus 2020 Revised date: 7 September 2020
Accepted date: 24 September 2020

\section{INTRODUCTION}

In language learning, especially in learning English as Foreign Language (EFL), English learning process has a goal to develop students' communication skills to deliver their thoughts and feelings to maintain their relationship with other people (Brummelen, 2009: 18). To achieve the purpose mentioned above, both teacher and students have a responsibility to develop effective learning by building interaction between students-students and teacher-students. The teacher should deliver the lesson effectively to make sure the students understand about what is being taught, while the students are expected to participate actively in comprehending, exploring, and applying the knowledge delivered in the learning activities. Wade in (Abdullah, Bakar, \& Mahbob, 2012: 516) stated that if students are active to contribute in class, they could enjoy sharing ideas with their friends and learn more about the lesson. It can be said that students' participation is an important element in the learning process to make an effective learning process.

According to previous studies, responding to the teacher's questions, asking questions, sharing opinions, thoughts, and ideas in the discussions are the indications that prove students' involvement and engagement in the classroom (Fredricks, et al., 2011: 2) Therefore, in general, classroom participation demands the students to participate verbally and interact with others to show that they follow, learn, and pay attention during the lesson without being asked by the teacher. Therefore, students' verbal contribution is essential for class participation because active learning can be achieved when all students participate in verbal actively.

Students' verbal participation is essential for language acquisition (Hamouda, 2013: 18). It is believed that verbal participation gives a chance for the students to practice the words and structures that they have learned in the real-life situation, helps the students to bridge the gap between what they know about English, what the thoughts they want to say, and how they will speak out their thoughts, and helps the students to deal with their lack of language and develop the language system by receiving feedback from others so they could produce appropriate language while speaking and build their English skills.

Nevertheless, one of the greatest challenges for English teacher during teaching and learning process is to gain students' verbal participation in English class. Even though the teacher always tries to encourage students to participate, but the students remain silent and do not actively participate during 
the English class. This condition also happened in one class in one of the private schools in Jakarta, according to the observation $\log$ and teaching reflection, it is found only 5 out of 26 students did verbal participation through giving opinions, and asking or answering questions. Moreover, the teacher who teaches English in this class is still struggling to find suitable teaching strategies that can make the students want to participate verbally during the English class.

Based on the facts and the explanation above, there is an urgency in students' lack of verbal participation which can inhibit both the students and the teacher in achieving an effective English learning, therefore this study tries to identify what are the factors that influence students' lack of verbal participation in English class and suggest some teaching strategies that can be used by the teachers to improve students' verbal participation in English class

\section{LITERATURE REVIEW}

Previous studies have shown some factors influenced students' verbal participation in the learning process. The first factor is students' self-efficacy that gives an impact on how they will contribute and perform during the learning process (Hsieh \& Kang, 2010: 607-608). Bandura in Raoofi, Tan, \& Chan (2012: 61) mentioned self-efficacy is students' beliefs about their impression towards the lesson and their abilities to do the task. Students who have high self-efficacy are better to perform and acquire English language rather than students who have lack of self-efficacy. Furthermore, self-efficacy determines students' self-confidence to participate verbally in English class. It is supported by McCroskey \& Richmond in Ghanbarpour (2016: 2266-2267), foreign language students who have low self-confidence tend to avoid participating in the learning. It means students will participate verbally when they have self-confidence to speak in English to express their thoughts, giving comments, asking or answering the questions.

The second factor that influences students' verbal participation is the fear of making mistakes while speaking English and being laughed at by others. The previous studies found some of the students did not participate in English class because they were afraid of making mistakes, such as grammatical errors and mispronouncing words, which makes them feel less competent, being laughed at by other students, and receive negative comments from their friends (Savasci, 2014: 2685).

The third factor is the lack of preparation before the English class begins. Indrianty (2016: 31) stated that one of the reasons why students afraid to participate verbally in English class is because of the lack of preparation before the class begin. Meaning that students will feel less afraid in speaking English if they have enough preparation whether in giving comments, answering, or asking questions, and sharing the ideas.

The last factor behind students' lack of verbal participation in English class is negative teacher's traits and personality. This factor is supported from the previous research by Nair, et al. (2014: 135) and Qashoa in Al-Khairy (2013: 377), they found that teacher who has negative traits and has humiliating ways to correct students' mistakes will create students' anxiety to speak in front of others. In short, if the teachers produce negative traits and responses toward students' answers, thoughts, and mistakes, it means they discourage students to learn and participate verbally in English class.

There are some teaching strategies that can be used by English teachers to enhance students' lack of verbal participation. The first one is Cooperative Learning (CL) which define as an organized learning activity done in a group so the students receive the knowledge based on the information shared between other students in the group (Olsen \& Kagan in Hidayati, Kharisma, \& Satriani, 2018: 18). CL has been shown to improve students' confidence and make students feel comfortable to participate verbally because each student will have greater opportunity to share their thoughts with their group (Peterson \& Miller in Bulut, 2009: 24)

The second teaching strategies could be used to encourage students to participate verbally is Contextual Teaching Learning (CTL). According to West \& West, (2009: 21), CTL is a teaching and learning process to help students connecting the knowledge during learning with their daily lives. Harmer (2009: 41-42) found that students better to comprehend the concepts delivered when they can relate the information with their real-life. In the context of learning English, CTL could engage the students to participate verbally because students will communicate about their experiences related to the new concepts so the students will be more comfortable and confident to share their ideas because they feel familiar with the topic being discussed (Wahyuni, 2013: 146). 
The last strategy is Inquiry-Based Learning (IBL). IBL is a learning process which students' observations, questions, and ideas become the center of the learning (Capacity Building Series [CBS], 2013: 2). Irawan, Syahrial, \& Sofyan (2018: 60) stated that IBL allows the students to investigate, explore, questioning, answering, and share their thoughts with other learners. It means IBL could motivate students to engage in the learning process which leads to their verbal participation in the learning process. Therefore, through implementing IBL in teaching English, besides help students in being thoughtful, innovative, and critical, IBL also encourage them to participate verbally in the classroom.

\section{METHODOLOGY}

The methodology of this study is qualitative case study research to explore a case or multiple case through detailed and in-depth data collection, then report a case description and case-based themes. This research tries to explore what are the factors behind students' lack of verbal participation in English class.

Moreover, to get the detailed information regarding the factors influence students' lack of verbal participation, a 5-point Likert scale questionnaire was used in this research. The questionnaire used in this study consist of 25 statements adapted from instruments used in the previous studies (Chang, 2011: 21-22; Hamouda, 2013: 21-22; Toubot, Seng, \& Abdullah, 2018: 52-53). The subject of this research were 26 students of grade VIII in one of the private schools in Jakarta.

In this study, the researcher discussed the problem with English teacher who teaches the subjects and then distributed the questionnaire to two English teachers in that school. Those two English teachers were asked to check the appropriateness of each statement and both of them suggested some modifications in the arrangements of some statements. The results were analyzed using thematicanalysis methods which is the process to identify patterns within the data and use the patterns to address the issue or the research.

\section{RESULT AND DISCUSSION}

According to questionnaire spread to the subject, the researcher found the lack of students' verbal participation in English class happens because of some factors which are the fear of teacher's responses and behavior, lack of self-efficacy in English lesson, lack of self-confidence, lack of preparation before the class begins, and the fear of making mistakes and being laughed at by others. The results can be seen from the diagram below:

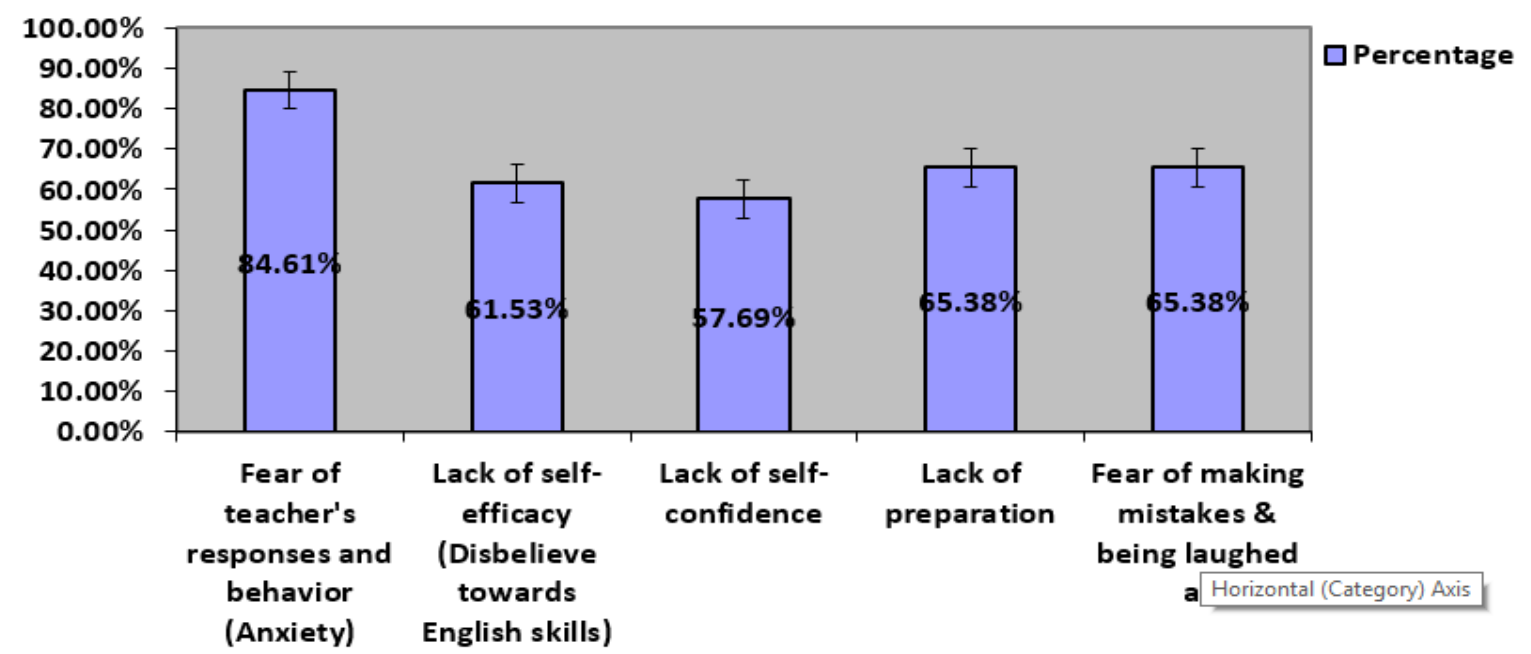

Picture 1. Factors Influencing Students' Lack of Verbal Participation in English Class 
The fear of teacher's responses and behavior. The results show $84,61 \%$ of the students having anxiety towards teacher's responses and behavior. One of the examples of this factor is the students confirmed that their English teacher is strict which becomes the teacher's trait to the students and indirectly discourage the students to do verbal participation during the learning process.

This finding is in line with the previous study saying that teachers' character could make the students do not want to participate actively in the class (Qashoa in Al-Khairy, 2013: 377). Moreover, when the researcher talked with the students, most of them think their teacher is rigid, fierce, and unfriendly so the students were afraid with the teacher,

The lack of self-efficacy in English lesson. From the results, $61,53 \%$ of the students are not sure with their English skill. One of the condition that represent this factor is when the students did a role play, most of them were spoke in Indonesia then the teacher asked them to talk in English, but they said that they are not able to speak in English. Moreover, because the students having bad impression about their teacher, it causes the students to have bad impression also with English lesson, they said that English is difficult lesson. As found by Ismail \& Majeed (2011: 104-105) that negative impression towards the teacher causes the students to have lack of self-efficacy about the lesson and their ability.

As mentioned above that self-efficacy is people's belief about the lesson and their ability related with the lesson (Bandura in Raoofi, Tan, \& Chan, 2012: 61), hence this results show most of the students in this class have low self-efficacy in English lesson and it determines their verbal participation in the class. This finding is in line with the previous study saying that self-efficacy impacts students' performance in learning language (Hsieh \& Kang, 2010: 607-608).

The lack of self-confidence. The results show $57,69 \%$ of the students are not confident with their speaking skills, and it shows the students have low self-efficacy which raises their shyness to participate verbally during the class. One of the conditions related with this factor is most of the students did not perform well in the group presentation; the volume of their sound was soft, so their speaking was not clear, and they looked nervous while speaking. Therefore, it is true there is a connection between self-efficacy and self-confidence, as stated by Bandura in Ahmad \& Safarian, (2013: 22) students' self-confidence in the lesson is determined by their self-efficacy towards the lesson. Other than that, it is confirmed that students who have low self-confidence tend to avoid verbal participation in English lesson. As found by McCroskey \& Richmond in Ghanbarpour (2016: 2266-2267) that the low of self-confidence will make students choose to do not speak out their thoughts and ideas.

To improve students' self-efficacy and self-confidence, the teachers could use Inquiry-Based Learning (IBL) in English lesson. IBL helps the students to change their perspective about their skills, Lee (2014: 1237) stated that applying IBL in second or foreign language class makes the students realize they must optimize their abilities to achieve meaningful learning so they will appreciate their abilities. Moreover, if the students have a good impression with their abilities, it raises their self-confidence to participate verbally because they will engage to communicate with others. This statement is supported by a previous study by Gurler (2015: 15), he found that students will have high self-confidence to speak if they aware and love their abilities. According to a research conducted by Irawan, Syahrial, \& Sofyan (2018: 62-63) there are five stages in implementing IBL to improve students' speaking, which are: (1) Asking stage, the teacher gives the topic of the lesson and allows the students to made questions related with the topic, (2) Investigating stage, the teacher directs the students to find the information about the topic, (3) Creating stage, the teacher asks the students to make a list of questions according to their finding in the previous stage, (4) Discussing stage, the students will discuss in groups about the topic, and (5) Reflecting stage, the students make conclusion about the topic.

The lack of students' preparation before the English class begins. According to the results, $65,38 \%$ of the students will not participate verbally in English class because they have not prepared in advance about the lesson. It may be considered that all the students do not have enough prior knowledge about the topic being discussed so they are not able to deliver their ideas or answer teacher's questions, this condition leads to the lack of students' verbal participation in English class. It can be seen during the learning process; the students could not answer teacher's questions about one topic and its because they were not familiar with the topic being discussed. Therefore, it is correct that students' preparation about the lesson influences students' verbal participation, as stated by Indrianty (2016: 31) that students will avoid participating verbally during the learning process if they do not have enough preparation about the lesson. 
To help the students in having enough prior knowledge, the teachers could apply Contextual Teaching Learning (CTL) during English lesson. CTL provides a learning process which relates the lesson with students' experiences or real-life condition so the students could be familiar with the topic being discussed. It is proved that students will be more courage and relax to deliver their thoughts if they familiar with the topic because they have prepared for anything that they want to speak. Therefore, CTL could engage the students to do verbal participation because they will share their experiences and condition based on the topic being discussed (Wahyuni, 2013: 146). There are some activities as the tools in applying CTL in the classroom which to improve students' speaking. First, storytelling which gives a real picture of ideas, individual experiences, beliefs, and life lesson through stories that stimulate students' feeling and thoughts. Wendlin in Roza, Rafli, \& Rahmat (2019: 46)

said that storytelling activity can help the students to improve their communication skills through sharing experiences during the learning process. Second is newscasting which allows the students to deliver and explain news to the audience properly, and it can be used as their practice to have good communication skills. Lastly is drama which it can be used as a creative way of learning that involves students to cooperate and at the same time develop students' creativity in the learning process (Guliyeva, 2011).

The fear of making mistakes and being laughed at by others. Based on the results, $65,38 \%$ of the students have the fear of making mistakes while participating verbally which makes them do not want to participate in English class. Another thing, the results also prove that most of the students are afraid of being laughed at by others if they are making mistakes while deliver their ideas or answer the questions. This means, most of the students have anxiety if other students will laugh at them because of their mistakes when doing verbal participation. Therefore, it is confirmed that students who have fear of being laughed at by others because of committing mistakes tend to avoid to do verbal participation and join in the class discussion, as found by Savasci (2014: 2685) that students' lack of participation in English class happens because their fear of being laughed at by others when they are committing mistakes or errors.

To overcome students' fear of making mistakes and being laughed at by others, the teachers could integrate Cooperative Learning (CL) in English lesson. CL trains the students to be aware of the different concepts appeared in their group, how to help others to overcome challenges and difficulties, and to make decisions based on various information to reach the goals of the learning. This statement is evidenced by Palmer, Peters, \& Streetman in Lombardi (2019: 121-122) they believed CL could help the students to accept differences and mistakes as the learning process and encourage the students to support each other in order to accomplish learning goals, thus CL could reduce students' fear of making mistakes and being laughed at by others through creating cooperative situation. One of CL techniques that can be applied to help students increasing their verbal participation is Round Robin Discussion. Round Robin Discussion involves the students to develop their ideas in a group through building up in turn contributions from each student in verbal form (Sibanda in Sripradith, 2019: 154). Barkley, Major, \& Cross (2014: 108-111) said that Round Robin Discussion is an effective tool to generate ideas within the students because each student will have same opportunity to express their thoughts related with the topic being discussed. Further, since Round Robin Discussion does not allow the students to give comments or interupt when one student is explaining the ideas, therefore it helps the students to learn about receiving different perspectives, exploring new concepts, and enhancing team building effort to get final conclusion about the topic.

\section{CONCLUSION AND RECOMMENDATION}

The present study shows there are five factors that influence students to not participate verbally in English class, which are the fear of teacher's responses and behavior, lack of self-efficacy, lack of self-confidence in speaking English, lack of preparation of English lesson, and the fear of committing mistakes and being laughed at by others. To overcome this problem, the researcher suggests some teaching strategies that can be applied to improve students' verbal participation in English class which are Cooperative Learning (CL), Inquiry-Based Learning (IBL), and Contextual Teaching and Learning (CTL).

Based on the finding and discussion in this study, teachers should realize that their identity gives a great influence in the teaching and learning process. The researcher suggests teachers to build 
good impression and learning situation so the students will be more comfortable to participate verbally in the class. Teachers could give positive reinforcement to the students, appreciate students' ideas or thoughts, and encourage the students to always keep trying even though their answers are wrong. Moreover, teachers need to apply various teaching strategies to gain students' verbal participation in the class. In addition, by knowing the results of this study, the next researchers may do further research by emphasizing on the correlation between students' verbal participation in class with their Englishspeaking ability.

\section{REFERENCES}

Abdullah, M., Bakar, N. R., \& Mahbob, M. H. (2012). Student's participation in classroom: What motivates them to speak up? Procedia-Social and Behavioral Sciences, 51, 516-522.

Ahmad, A., \& Safarian, T. (2013). Effects of self-efficacy on students' academic performance. Journal of Educational, Health and Community Psychology, 2(1), 22-29.

Al-Khairy, M. H. (2013). English as a foreign language learning demotivational factors as perceived by Saudi undergraduates. European Scientific Journal, 9(32), 365-382.

Barkley, E. F., Major, C. H., \& Cross, K. P. (2014). Collaborative learning techniques: A handbook for college faculty (2nd ed.). Hoboken, NJ: John Wiley \& Sons.

Brummelen, H. V. (2009). Berjalan dengan Tuhan di dalam kelas: Pendekatan Kristiani untuk pembelajaran. Jakarta: Universitas Pelita Harapan Press.

Bulut, S. (2009). The effect of cooperative learning techniques on pre-service teachers' self-esteem, achievement, and absences. Suvremena Psihologija, 12(1), 23-41.

Capacity Building Series [CBS]. (2013, May). Inquiry-based learning. Inspire (The Journal of Literacy and Numeracy for Ontario, 1-8. Retrieved from http://www.edu.gov.on.ca/eng/literacynumeracy/inspire/research/cbs_inquirybased.pdf

Chang, F. y. (2011). The causes of learners' reticence and passivity in English classrooms in Taiwan. The Journal of Asia TEFL, 8(1), 1-22.

Fredricks, J., McColskey, W., Meli, J., Mordica, J., Montrosse, B., \& Mooney, K. (2011). Measuring student engagement in upper elementary through high school: A description of 21 instruments. Washington DC: Regional Educational Laboratory Southeast.

Ghanbarpour, M. (2016). Willingness to communicate, linguistic self-confidence, and language-use anxiety: The Iranian EFL context. Theory and Practice in Language Studies, 6(12), 2265-2271.

Guliyeva, G. (2011). The role of drama in language teaching. 1st International Conference on Foreign Language Teaching and Applied Linguistics, (pp. 521-524). Sarajevo.

Gurler, I. (2015). Correlation between self-confidence and speaking skill of English language teaching and English language and literature preparatory students. Curr Res Soc Sci, 1(2), 14-19.

Hamouda, A. (2013). An exploration of causes of Saudi students' reluctance to participate in the English language classroom. International Journal of English Language Education, 1(1), 17-34.

Harmer, B. M. (2009). Teaching in a contextual vacuum: Lack of prior workplace knowledge as a barrier to sensemaking in the learning and teaching of business courses. Innovations in Education and Teaching International, 46(1), 41-50.

Hidayati, L. A., Kharisma, I., \& Satriani, I. (2018). Students' perception in applying cooperative learning in EFL classroom. ETERNAL (English, Teaching, Learning, and Research Journal), $4(1), 16-30$.

Hsieh, P. P.-H., \& Kang, H.-S. (2010). Attribution and self-efficacy and their interrelationship in the Korean EFL context. Language Learning: A Journal of Research in Language Studies, 60(3), 606-627. 
The Factors Influencing Grade VIII Students' Verbal Participation In English Class

(Stakisia Puteri Pradestina, Atalya Agustin)

Indrianty, S. (2016). Students' anxiety in speaking English (a case study in one hotel and tourism college in Bandung). ELTIN Journal, 4(1), 28-39.

Irawan, Y., Syahrial, \& Sofyan, D. (2018). The effect of using inquiry based learning strategy on students speaking ability (a case study at SMAN 7 Bengkulu Selatan). JOALL (Journal of Applied Linguistics and Literature, 3(2), 59-79.

Ismail, Z., \& Majeed, A. (2011). Student self esteem and their perception of teacher behavior: A study of class grouping system in Pakistan. International Journal of Business and Social Science, 2(16), 103-113.

Lee, H.-Y. (2014). Inquiry-based teaching in second and foreign language pedagogy. Journal of Language Teaching and Research, 5(6), 1236-1244.

Lombardi, P. (2019). Instructional methods, strategies and technologies to meet the needs of all learners. PressBooks.

Nair, G. K., Setia, R., Samad, N. Z., Zameri, N. N., Luqman, A., Vadeveloo, T., \& Ngah, H. C. (2014). Student and lecturer attributes and university setting in nurturing oral proficiency. Asian Social Science, 10(3), 129-137.

Raoofi, S., Tan, B. H., \& Chan, S. H. (2012). Self-efficacy in second/foreign language learning contexts. English Language Teaching, 5(11), 60-73.

Roza, A. S., Rafli, Z., \& Rahmat, A. (2019). The implementation of contextual teaching learning (CTL) to improve the students' speaking ability in Islamic studies course. International Journal of Applied Linguistics \& English Literature, 8(4), 45-50.

Savasci, M. (2014). Why are some students reluctant to use L2 in EFL speaking classes? An action research at tertiary level. Procedia-Social and Behavioral Sciences, 116, 2682-2686.

Sripradith, R. (2019). An investigation of the round robin brainstorming in improving English speaking ability among Nakhonphanom University's second year students in Thailand. Journal of Education and Learning, 8(4), 153-160.

Toubot, A. M., Seng, G. H., \& Abdullah, A. b. (2018). Examining levels and factors of speaking anxiety among EFL Libyan English undergraduate students. International Journal of Applied Linguistics \& English Literature, 7(5), 47-56.

Wahyuni, E. S. (2013). The application of contextual teaching learning using react in speaking practices for business English class. Magister Scientiae, 34, 145-158.

West, J. A., \& West, M. L. (2009). Using wikis for onlinr collaboration: The power of the read-write web. San Fransisco: Jossey-Bass A Wiley Imprint. 